\title{
ORGANIZATIONAL CHANGE
}


Other titles from The Macmillan Press

Macmillan Business Management and Administration SERIES

edited by Alan Hale

David Brown and Michael J. Harrison: $A$ Sociology of Industrialisation: an introduction

Terry Green and John Webster: Managing Mathematically

Peter Haine and Ernest Haidon: Computers in Business

Arthur Hindmarch, Miles Atchison and Richard Marke: Accounting: an introduction

Peter Ribeaux and Stephen E. Poppleton: Psychology and Work: an introduction 


\section{Organizational Change}

\section{The Managerial Dilemma}

Edmund Brooks 


\section{(C) Edmund Brooks 1980}

Softcover reprint of the hardcover 1st edition 1980 978-0-333-26691-5

All rights reserved. No part of this publication may be reproduced or transmitted, in any form or by any means, without permission.

First published 1980 by

THE MACMILLAN PRESS LTD

London and Basingstoke

Associated companies in Delhi Dublin

Hong Kong Johannesburg Lagos Melbourne

New York Singapore and Tokyo

British Library Cataloguing in Publication Data

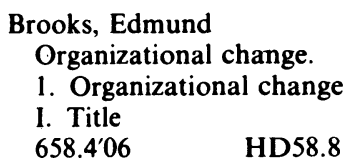

ISBN 978-0-333-26692-2 ISBN 978-1-349-16346-5 (eBook)

DOI 10.1007/978-1-349-16346-5

This book is sold subject to the standard conditions of the Net Book Agreement.

The paperback edition of this book is sold subject to the condition that it shall not, by way of trade or otherwise, be lent, resold, hired out, or otherwise circulated without the publisher's prior consent in any form of binding or cover other than that in which it is published and without a similar condition including this condition being imposed on the subsequent purchaser. 
This book is dedicated

to Gail

who changed certain elements of my life 


\section{Contents}

$\begin{array}{ll}\text { Preface } & \text { ix }\end{array}$

Acknowledgements xii

Introduction xiii

1 The Problems of Managing Organisational Change 1

2 Theories and Approaches to Managing Organisations 32

3 An Organisational Framework for Managing Change 72

4 The Social Organisation of Work 110

5 Changing the Structure of Organisational Operations 135

6 Developing a Learning Organisation 157

7 Managerial Strategies of Organisational Control 189

8 The Management of Organisational Change 219

$\begin{array}{ll}\text { Index } & 243\end{array}$ 


\section{Preface}

The book begins, in Chapter 1, with a study of the pressures and demands made by the economic and business environment upon organisations and the responses of management to the problems directly affecting organisational systems of operation. The chapter identifies the major stumbling-blocks in organisational (work) relations which frustrate and undermine the collaboration needed by specialist functions in large complex organisations in order to resolve operational problems directly affecting business performance.

Chapter 2 examines and appraises the different schools of management thought which have contributed to an understanding of the problems and issues facing managers concerned with improving the performance, efficiency and operating capability of organisations. The focus of this chapter is upon the co-ordination and control of operations - the need for developing and sustaining co-operation, the nature and character of organisational decision-making processes, the application and manipulation of bureaucratic rules by different interest groups, and the need for organisations to adapt their structure and functioning to meet the needs of a changing environment.

Chapter 3 provides a conceptual framework for understanding the structure and functioning of organisations. It highlights the principal policies and tasks of organisations such as product development, quality control, cost control, resource management, etc. The various possible technological methods and modes of operation are viewed in terms of their contribution to management's efforts to schedule and organise the work flow and to control administrative procedures and working practices. In that an organisation's structure attempts to define and prescribe work relations, an assessment is made of how the 
autonomy and power of specialist functions are affected by organisational hierarchies of authority, work specialisation, the institutionalisation of rules and regulations and by different degrees of centralisation and decentralisation of the decision-making process.

Attention is then focused upon the needs and interests of organisational members and upon the conflict with the goals of the organisation, which is highlighted by resistance to managementdirected change. Recognition is given to the influence of work groups and the controls they exert upon various work systems.

Chapter 4 examines and puts to the test the beliefs and assumptions underlying management's efforts to reorganise and rationalise work systems and the tasks of organisational members. The findings of research on job enrichment, work motivation and autonomous work groups are looked at in terms of how far they may have contributed to improved job performance. The essential consideration is in establishing what the necessary and sufficient conditions for changing work patterns are, and the demands this imposes upon the manager and his style of management.

Chapter 5 identifies serious malfunctions in the structure of organisational operations and critically examines and questions whether management has sufficient control over individual and group actions to reorganise and rationalise work systems more productively. One of the principal aims of the chapter is to set out some of the necessary preconditions for planning and implementing changes in the structure and function of organisational systems of operation. Serious thought is given to the problems and constraints facing management in implementing organisational change.

Chapter 6 questions and challenges the value of traditional management training in organisations and introduces new viable alternative strategies of human-resource management as a necessary condition for achieving organisational change and development. The principal finding is that organisations cannot effectively release its managerial potential in solving business problems which frustrate overall performance objectives without changing the organisation's climate of working.

Chapter 7 seeks to pinpoint the causes and consequences of the factors which undermine managerial control over business operations. A critical assessment is made of how managers may best come to terms with the nature of power, authority and control of organisational members over changes directed at improving methods 


$$
\text { Preface xi }
$$

and modes of operation. The next step involves identifying appropriate management change interventions which remove some of the principal barriers to change.

Pressures for organisational change are invariably resisted in periods of economic uncertainty when the perceived outcomes of the changes to be made threaten to dislocate or disrupt systems of operation.

The final chapter seeks to establish how management can maintain effective control and influence over changes made necessary in a company's mode of operation. A strategy is devised for improving managerial accountability for operational control and for securing greater support and commitment to organisational-change initiatives.

References and Further Reading lists are to be found after the appropriate chapters.

E.B. 


\section{Acknowledgements}

Writing a book is a solitary experience. It could not have been achieved, however, without the advice, support and wisdom of others. I should like to acknowledge some of the people I worked with professionally in organisations. Cliff Woods, Peter Gill and Brian Wallace were former colleagues of mine whose experience and knowledge of organisational change and development was invaluable. I owe a special debt to Jack Lang for providing me with the opportunity to undertake several projects and field work investigations, and to Phil Gibbons whose forward thinking and innovative efforts to improve business operations gave me the impetus for developing my ideas about organisational change.

The editors of Industrial and Commercial Training and European and Industrial Training have kindly permitted me to include material from my articles published in their journals.

Several of my friends have listened patiently to and read several passages of the book. I would like to thank Cleve and Vicky Baker, Derek Moul and Maurice Rosewell for their interest and encouragement. Richard Loundes and Dr Paisey were kind enough to review drafts of certain chapters.

A final but special mention must be made of Gail Hart-Porter for the time and effort she put in, not only reading and editing the chapters, but in helping me to clarify my ideas and forcing me to think through some of the problems and issues I faced in writing this book. 


\section{Introduction}

Modern industrial society has witnessed the breath-taking pace of technological change from the time of the development of the combustion engine. Yet the application of advanced technology entails considerable risk in capital investment which in the cases of Rolls-Royce and Concorde has proved to be financially disastrous. Certain enterprises are surviving only because of government aid. Industries such as newsprint, steel-making and textiles have been unable to modernise systems of operation and consequently have found themselves in serious decline.

The resistance of unions to technological change and the use of industrial sanctions in the car industry, for example, has dramatically affected the competitiveness of British car firms. With the growth of union power, and the increasing dependence of large organisations on sophisticated technical controls such as computers, there is always the threat of industrial action being taken which seriously undermines the predictability of normal business operations. Economic stability and industrial order are essential for managers to regulate and control systems of work.

Organisations are increasingly experiencing a lack of control over their work environment in the face of economic and social change. There is a very real crisis of confidence among management today, in its ability to cope and adapt to the pace of change in modern industrial society. There is, for example, an inability in almost all organisations to accept and know how best to come to terms with the idea of worker directors. There is grave concern and a fear of the fundamental clash of interests and the consequences for the viability of commercial companies. The challenge to managerial control is the key factor in explaining such a crisis of confidence. The failure of 


\section{xiv Introduction}

managerial performance controls which are served by computerised information-retrieval systems and various management techniques of objective-setting and work measurement to identify the efficiency of business operations undermines the already shaky foundations, or rather notions, of managerial authority.

Management is uncertain whether to combat or yield to pressures for change. There is increasing uncertainty as to how best to adapt the organisation's structure and functioning to meet the needs of a changing environment, without undermining its own power and authority. This is the dilemma that managers find themselves in. Managers will be unable to evolve radically new methods and modes of tackling the problems which beset them until the conflicts of interest and the struggle for power and authority are resolved within organisations. This book will address itself to these problems and issues.

New managerial strategies of work regulation and control are needed. There is, however, a basic lack of managerial skill in diagnosing and implementing the necessary changes in an organisation's structure and mode of operation. At the same time, organisational structures are insufficiently adaptive to change, due to inflexible procedures and boundaries between specialist functions, which consequently frustrate the close collaboration and joint problem-solving which is needed in order to overcome outmoded methods of business operation. This book questions and challenges the constraints of traditionally outmoded organisational procedures and managerial practices.

The challenge laid down before management is that of creating a new, more productive and innovative climate of working. There is a strong body of opinion based on the literature published to date which believes that more profitable companies happen to be decentralised, have a participative system of management and adopt sophisticated control and information systems. The problem is, however, in explaining why such firms are more effective than other comparable organisations. The answer lies in being able to understand and explain how they are operationally more successful. This book is written to that end. 